\title{
COLLECTIVE HOUSING AS NEW IDENTITY IN RURAL AREAS
}

\author{
DOI: 10.18485/arh_pt.2020.7.ch53
}

\begin{abstract}
_ Miloš Arandjelović
PhD, Associate scientist,Faculty of Architecture University of Belgrade, Bulevar Kralja Aleksandra 73/2, mls.arandjelovic@gmail.com
\end{abstract}

\author{
_ Aleksandar Videnović \\ $\mathrm{PhD}$, Associate Professor, Faculty of Architecture University of Belgrade, \\ Bulevar Kralja Aleksandra 73/2, videnovic.a@gmail.com
}

\begin{abstract}
Changes in the social and cultural pattern have led to some changes in the forms of rural housing. Especially in the post-war period, more precisely 70's and 80's of the twentieth century, which represents the research timeframe. One of the main reasons for this is certainly the process of postwar intensive industrialization, while the other lies in the need to improve the basic amenities and services of the settlement. The paper describes the collective housing in rural areas built in Serbia as a former republic of socialist Yugoslavia. Collective housing in the countryside appears to be a real need for working class accommodation employed in industrial plants as well as housing for government officials and workers of public institutions (post office, police, schools, etc.). The architecture of these buildings, on the other hand, did not possess the features of regional and traditional architectural values. It belonged to a different practice embodied in the values of socialist ideology. It should also be added that the construction of such buildings was not characteristic for all forms of rural settlements. These were predominantly rural settlements of higher category which had well established centers and other elements of urban structure as well as solid demographic potential. In this sense, the research seeks to point out some relevant specifics of such construction on the one hand, and on the other to point out some of the possibilities for future spatial and functional organization of rural settlements.
\end{abstract}

KEYWORDS _ collective housing, rural identity, socrealism in architecture, industrialisation and village

\section{INTRODUCTION}

The analysis of the social context in which the construction of rural collective housing facilities took place is undoubtedly important for the understanding of that process. It is primarily necessary because it indicates certain specific characteristics of that practice. Namely, the nature of the need for such form of housing in the communities traditionally characterised by agricultural activity and the connection with the soil. Accordingly, this study recognizes the shift in life styles and economic activities in rural areas as one of the main reasons for changes in the housing models.

The analysis of the original context of the construction of these buildings in the Serbian villages is linked to the period of post-war construction efforts and the planning of rural settlements in accordance with the socialist principles. The massive state-promoted push towards the intense industrialization of the Yugoslav society at the time demanded additional workforce, which usually came from rural areas. Employment in plants increased the demand for worker housing so the factories 
erected in rural communities have themselves constructed collective housing facilities, but also entire worker settlements for their own needs.

This study is relevant since the trend of diminishing agricultural production continues to this very day. Contemporary rural development strategies increasingly strive to find the ways for keeping the population by means of economic sector improvement, while, on the other hand, few of them focus on manner and quality of life of people in rural communities. Tourism, specialized agricultural production and other possible forms of rural economic activity are promoted, while the issue of housing is somehow taken as granted and remains in the context of individual free standing houses. In that sense it is important to indicate some of the forms of housing which could, and logically should, follow the current settlement development, and where such forms were previously present in the construction practice in Serbia, although in a specific historical context.

From the point of view of methodology, this study represents the analysis of the aforementioned social context which has defined the construction of collective housing facilities, but it also notes some of the examples of this construction such as the buildings in settlements Crna Trava and Kalna on Stara Planina Mountain. By providing specific cases we endeavour to review not only the negative aspects of such construction in villages, most often related to general criticism of socialist heritage, but also some of the advantages of life in such buildings.

\section{SOCIALIST CONSTRUCTION CONTEXT}

The changes on the planning and organization of rural settlements started immediately after the end of the Second World War. The architectural practice in socialist Yugoslavia was completely aligned with the social and political development trends. In the light of the idea of general socialist transformation of society, the program of agrarian reform and accelerated industrialization was imposed on the new state. The reform criteria and objectives notwithstanding, the industrialization was largely to be spearheaded by the rural population, thus achieving a double effect - the construction of industry on one hand, and the reform of the agriculture (which implied the creation of working class in villages) on the other (Stevanovic, 2008). From the viewpoint of those in power, the reasons for such efforts were completely justified since $70 \%$ of the population at the time lived in rural areas.

The aforementioned changes are relevant for this study simply because this is the moment when mass construction of collective housing buildings was initiated in rural communities. This construction was fuelled by the need for the housing of workforce which came from villages and was employed in plants. We should also note the housing of civil servants and other public employees in the rural communities (police officers, postmen, teachers and other school staff, etc.).

General efforts aimed at the resolving of the issue of rural housing were especially intensified in late 1950s and early 1960s. This is when the ambitious attempt was made to define certain correct housing postulates through specific designs for rural houses and households. The proposals of standardized houses for specific areas and regions in these cases implied individual buildings. The entire process was organized by the Institute of Hygiene of the People's Republic of Serbia which made an important step in the development and presentation of programme designs for both houses and rural yards with attached facilities (Simonović \& Ribar, 1993, pp. 140-142). However, the obstacles soon encountered in practice by both designers and numerous state institutions were related to the lack of funding for the implementation of the said ideas.

On the other hand, the architecture of collective housing buildings, which were also being constructed, had no specific traits linked the regional or traditional construction heritage, but was rooted in the new practice reflecting the values of the socialist ideology. The construction continued in this manner from 1950s up to 1990s. The efforts aimed at rural settlement planning and changes in living conditions in line with socialist ideas have initiated certain tangible spatial and functional changes in the villages, primarily from the aspect of rural hubs design which implied the construction of cooperative buildings and spatial planning of public areas (Aranđelović \& Videnović, 2016, pp. 947-960). 
Groups or individual examples of collective buildings are most often located in the central zones of settlements and as such used to be the models of new development and socialist urban planning. Unlike some examples being constructed today, the architecture of this period possessed a certain aesthetics and form accompanied with adequate quality of housing. On the other hand, today the fulfilment of minimal construction standards has become an excuse for development of an unacceptable rural architecture which represents a complete functional and aesthetical failure.

\section{ARCHITECTURE AS A REFLECTION OF A LIFESTYLE}

Rural architecture has historically usually followed a spontaneous manner of construction which was not implemented by professional organizations but arose as the need of the population building independently for their own needs. The construction knowledge and skills were transferred from generation to generation along with the respect for the tradition which directly influenced the architectural forms.

Traditional rural architecture has always reflected the needs of the people living and working in these areas. At first glance, such a statement seems completely self-evident; however the impact of different economic activities, from the aforementioned industrialization to modern tourism has considerably altered not only the needs but also the understanding of the very notion of rural housing. Collective housing as a concept is not inherent for rural areas. Link to agriculture as primary economic activity has largely determined the concept and rhythm of rural life. However, changes in the economy have, quite expectedly, engendered relevant changes in the concept of housing.

These and similar changes have also impacted the shift in the visual identity of rural settlements. Such is the case today in, for example, suburban settlements where semi-urbanized spaces are created between the urban and rural areas, and where these spaces tend to grow into settlements serving the needs of the near-by city, having in mind the fact that they offer lower costs of living then those in the urban centre.

Noting that man's survival depends, among other things, on the planned and designed image of the environment he inhabits, Christian Norberg-Schulz indicates the need for preservation of a specific location's identity, more precisely its existential space (Norberg-Schulz, 2006). Certainly, specific changes, even in small communities, are necessary due to shifts in lifestyles, communication and economic activities, but it is still important to understand the need for preservation of the original values of rural life, and accordingly the need for careful planning of future facilities.

When discussing spatial changes, it is irrelevant whether we refer to the shifts in forms of housing or economic facilities; the more important thing is to accept the fact that changes in social, economic and cultural spheres must be paired with the changes in the architectural shaping of space, since this provides the sustainability of a settlement in complex contemporary circumstances.

In that sense, Schulz notes that it is a duty of an architect to assist the man in defining his existential framework in line with the social guidelines which are almost constantly in the phase of turbulence and transformation, to adapt to the changes but also the preserve the values of the traditional context in order to avoid the loss of one's own identity.

Village houses and yards as basic elements of spatial organization of a rural district have always been a reflection of rural life. The construction of collective housing has in a certain manner represented the break with the traditional architecture continuity and was based on the creation of a new visual identity of rural settlements.

In the original socialist context the construction of collective buildings in the rural communities was a result of:

_ Changes in the domain of economy which contributed to the creation of a rural working class (employment in the industrial sector, agrarian reform consequences)

_ Strive for urbanization and spatial planning of settlements

(based on the idea of socialist transformation of villages - creation of new symbols)

On the other hand, we should still emphasize certain advantages of such a form of housing. Some 
of these are certainly:

_ Reduced communal needs;

- Settlement concentration which facilitates infrastructural planning, as well as provides additional acce3ssibiolity to different facilities (social protection, service and commercial facilities etc.);

_ Improvement in the quality of housing;

_ Settlement spatial planning in line with the professional rules and guidelines.

Maybe, in line with all of the aforementioned, it would be best to review the shifts in the functional and spatial composition of settlements in the light of a specific example. Until 1965, the village Kalna was the seat of the municipality consisting of 14 settlements. In 1963, uranium was discovered in the village Grabovica near Kalna, and at the time it was believed this would kick-start the economic development of the area. Intensive infrastructure improvement was undertaken and numerous public buildings and worker colonies were constructed. The construction of the mine and the attached settlement was stopped after two years, which was followed by the demographic shifts and migrations towards primarily Knjaževac and Zaječar as larger hubs.

According to the official 2011 Census few people remain in this settlement - only 289 and it is expected to completely disappear in a few years' time. However, the existing sound infrastructure and various facilities could be used to potentially revitalize the settlement (Aranđelović \& Videnović, 2016, pp. 69,70).

From the aspect of architecture, these buildings are aligned with socialist aesthetics, with a stronger focus on function than on external ornaments, but with clearly defined shapes and volumetry (Figure 1,2). They represented standardized designs produced by various professional organizations, so design-wise these were functionally well-designed buildings. The apartments were of no lower quality than those in the urban centres. The only issue that arose later on was that the buildings have seemingly lost their purpose after the mine was closed and the idea of ore processing was abandoned.
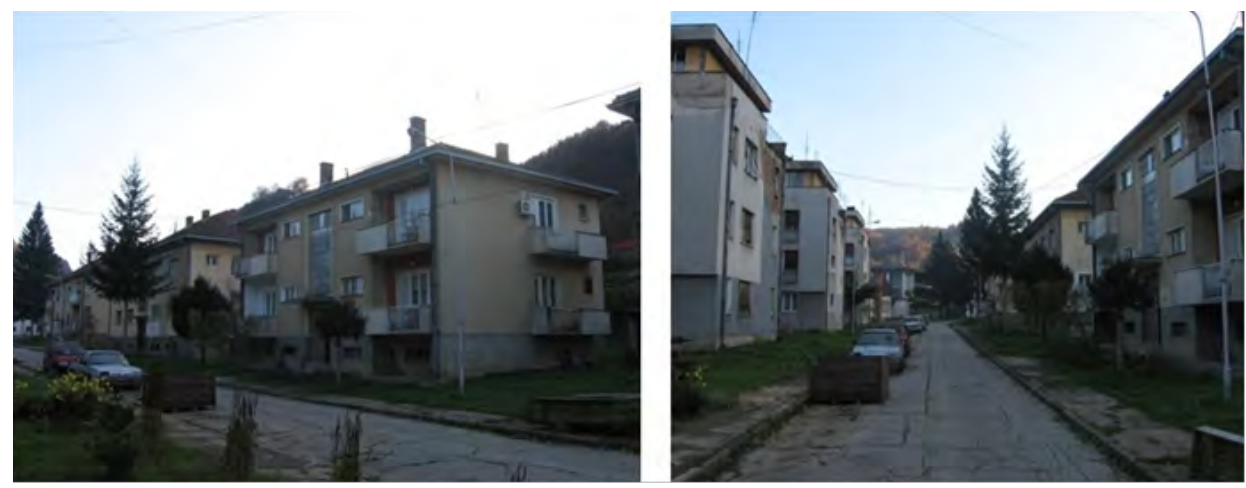

_ Figure 1,2: Settlement Kalna. Source: Authors archive

On the other hand, the study also refers to construction activities in Crna Trava as an example of individual collective housing buildings (Figure 3). From the aspect of urban planning, the newly constructed buildings have been aligned with the design of the central space and pedestrian zone in the settlement. They became the main elements of the settlements spatial plan. Built in 1970s and 1980 s mostly for the needs of the housing of workers employed in the newly opened furniture factories in Vranje and textile industry in Pirot, these buildings have become the visual symbols of the settlement. The only issue (that arose later on) was related to the inheriting of the apartments (Videnović, 2017, pp. 367-369). The heirs were not obliged to get employed in the same organizations in order to keep the ownership rights which later lead to different social shifts, mostly migrations. It is similar to the situation in Kalna, where the deterioration of factories without the option for continued 
employment or going back to intensive agriculture resulted in the population leaving their households in a search of a better life.

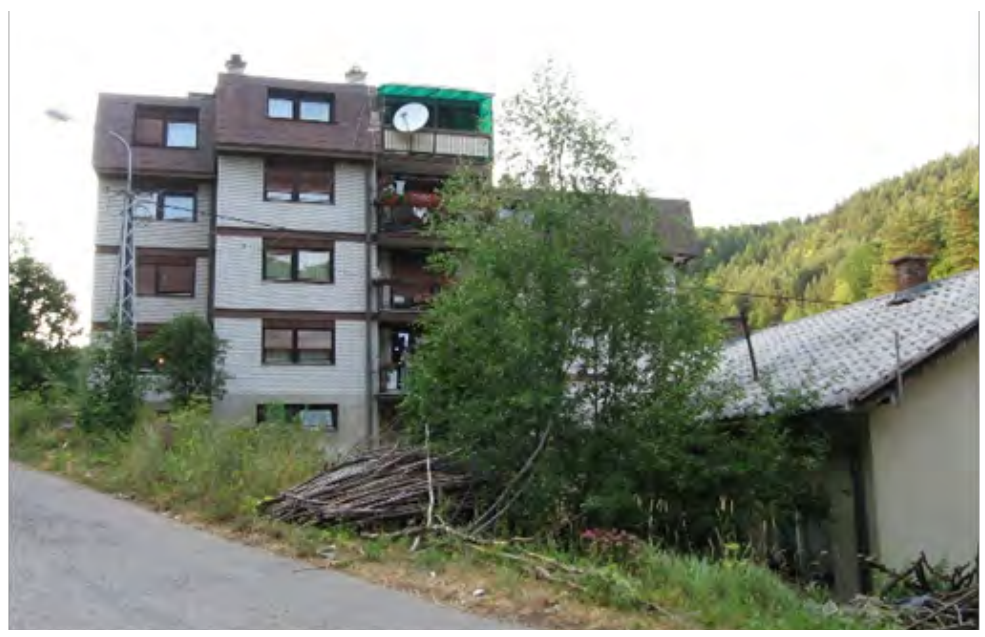

_ Figure 3: The facility for the needs of health and child care workers, built in the 1980s. (Crna Trava). Source: Authors archive

\section{CONCLUSIONS}

The study endeavours to indicate certain relevant specific traits of the collective housing construction on one hand, and the potential options for future planning of rural settlements on the other. Rural collective housing can represent a model for affordable housing at the present, especially having in mind that, in spite of numerous strategies, the percentage of agricultural population keeps dropping. Life in traditional rural households requires a lot of work on building maintenance and, understandably, considerable financial resources that the population that is not engaged exclusively in agriculture or doesn't see it as its chosen economic activity simply does not possess. In contemporary terms, collective housing can represent sustainable housing for non-agricultural population. However, the negative effect, that has been proven in practice as common for a considerable number of cases, is that several decades of crisis and sanctions that have affected our country, have encouraged a considerable number of people living in such buildings to resort to different forms of agriculture in order to survive these troubled times. This created a disbalance where people lived in apartments but worked in agriculture.

On the other hand, it is positive that the construction of these buildings was accompanied by the landscape design of the immediate surroundings. Quite often collective housing facilities were surrounded by public spaces, paved or green areas with benches and occasionally drinking fountains which enabled decent stay in the open. For the aspect of urban planning, this has enabled significant improvement of the spatial and functional potential of the settlement.

The original context of the socialist construction definitely demonstrates the importance of the state and competent professional organizations leading the entire process. Especially when having in mind the current practice of own-initiative construction governed by "investor urbanism" which frequently lowers the quality of the designed space, primarily because it is profit-oriented. The ideological and political framework from the socialist construction (and the negative image thereof) notwithstanding, the involvement of professionals remains important since it would reduce negative interventions in space which have been considerably degrading the look of the settlements in practice, their traditional identity and thus the living conditions in such an environment. 


\section{REFERENCES}

- Aranđelović, Miloš and Aleksandar Videnović. 2016. „Društveni značaj zadružnih domova u postsocijalističkom kontekstu." Zbornik Matice srpske za društvene nauke, 4/2016: 947-960.

_ Aranđelović, Miloš and Aleksandar Videnović. 2016. "Regional factor of sustainable development of rural settlements of Kalna and Minićevo at the foot of the Stara planina mountain." Spatium, No. 35 (june): 63-70.

- Videnović, Aleksandar. 2017. Obnova centara u ruralnim područjima. Beograd: Arhitektonski fakultet u Beogradu.

- Stevanović, Đura. 2008. Industrijalizacija poljoprivrede i budućnost sela. Beograd: Zavod za proučavanje sela.

- Simonović, Đorđe and Milorad, Ribar. 1993. Uređenje seoskih teritorija i naselja. Beograd: IBI.

- Norberg-Šulc, Kristijan. 2006. Egzistencija, prostor i arhitektura. translated by.Milutin Maksimović, Beograd: Građevinska knjiga. 